\title{
RE-INTERPRETING THE ROBINSON SKYPHOS
}

\author{
John D. Muccigrosso
}

\begin{abstract}
The scene on the Robinson skyphos was wrongly identified for years as a depiction of clay-working, either in a kiln or other preparation area. Recent scholarship has correctly identified it instead as one related to the grain harvest. This article presents a new examination of the scene, pointing out details the importance of which had not previously been noted. It also brings to bear comparanda from Egyptian art which put the identification of the scene beyond doubt.
\end{abstract}

To John Pedley, magister peritissimus

\section{Introduction}

The black-figure skyphos from the Robinson collection, dated to just before $500 \mathrm{BC}$, is decorated with an unusual scene attributed to the Theseus Painter. ${ }^{1}$ Most scholars have noted the atypical nature of the decoration, and it had been widely believed to show a pottery workshop ever since David Robinson's suggestion in the first published description of the skyphos (1938). Recent interpretations, led by Scheibler (1987: 7273), have instead seen it as agricultural in nature. My aim here is to show that this latter trend in the scholarship is correct and to point out hitherto neglected, though telling, ancient comparanda along with some of the reasons for the decades-long misinterpretation. A second, much more fragmentary scene from Thasos, which appears to be extremely similar to this one, has been recently published (Maffre 1999, here Figure 2). Considering the poor state of preservation of the Thasian skyphos, I will treat mainly the better known Robinson example, though a few features of this other version will be worth noting.

Both sides of the Robinson skyphos (Figure 1) present what is clearly the same scene with minor variations, a not uncommon feature of vases by the Theseus Painter (Borgers 2003; contra Fritzílas 2006a; Eisman \& Turnbull 1978). In the center, a shirtless man stands behind-or inside-a waist-high object in the shape of a truncated cone and decorated with hatching. To the far right is a herm in profile, facing this central figure. In front of the herm, between it and the central figure, stands another man, dressed in an himation, while to the left of the central figure, another man bends over at the waist, standing at the foot of the conical object, with a basket which has been turned on its side at his feet. Finally, to the left of this last figure, under the handle of the skyphos, is a bearded male with both hands on an amphora, sitting on the base of the herm from the scene on the opposite side (which faces away from him). In short we have an outdoor scene of men at work. But at work on what?

\footnotetext{
1 Now Harvard Museums 1960.321 and 1958.19, found at the Sackler Museum, where I had the opportunity to examine it at first hand in February 2011.

On-line: http://www.harvardartmuseums.org/art/289147. In the on-line Beazley Archive at the Classical Art Research Centre at Oxford (henceforth BACARCH), it is inventory number 330707.
} 
Robinson noted the absence of parallels to the central object and, after speculating that the scene might show men "building a wine-vat or tank or granary," settled on the construction of a kiln as the most likely subject. Subsequent scholars almost unanimously followed this same identification, sometimes sharing in his slight uncertainty. ${ }^{2}$ Later Eisman and Turnbull accepted the idea of the pottery workshop, but rejected Robinson's interpretation of the central conical object, preferring instead to see it as, on one side, a heap of clay, and, on the other, a settling tank (1978: 397). ${ }^{3}$ Several features of the scene have been positively cited for the workshop identification, but none is very strong, despite the early consensus view in the scholarship.

\section{Individual parts of the scene}

Although placed out of the way, the figure cited first by Robinson in favor of his workshop hypothesis was the youth with the amphora under the handles. This figure was subsequently described by Robinson as "fashioning a vase" (Robinson \& Hanfmann 1961: 15 inv. 76), yet there is little evidence in favor of this. ${ }^{4}$ To be sure, on both sides the figures hold the handles of their respective vessels with their left hands. ${ }^{5}$ The figure facing side A has his right hand open and placed on the shoulder of the amphora, very near his own left hand. He could perhaps be moving his hand, smoothing out the clay surface, but there is no spare clay around him, no wheel, no small pot for slip of paint. He is more likely just resting a hand on the pot as he sits. His seat, the herm's podium, also seems a bit unusual for a workman, even if we grant the painter some leeway to fit everyone into a crowded scene. ${ }^{6}$ There also are, as Scheibler notes (2000: 26-27), garlands around the vessel: on side A, the garland lies under the band on the neck indicated by the white lines, on B, inside that band, on the neck itself. It is possible that instead of an actual garland, some kind of painted or applied decoration is intended, or even an integral decoration made of some kind of different material (such as gilding, if we should understand a metal vessel), but any of these eliminates the possibility that the youth is working on an unfired clay vessel. ${ }^{7}$

Though usually treated as real finished objects of worship in the scholarship, the herms themselves have also been cited as evidence for the workshop interpretation. Robinson interpreted this part of the scene as an invocation for the successful completion of the work he believed to be taking place, but Eisner and Turnbull instead presented the herm as an integral part of the pottery workshop, comparing it to several other workshop depictions (1978: 398-399). There is however little evidence for such a use for herms in Greek art: their usual context is outdoor sacrifice. ${ }^{8}$ A few workshop-

\footnotetext{
2 Contrast Beazley's "uncertain subjects [building a kiln?]” (1956: 520.26) with Ure's “his skyphos with kilns in Baltimore" (1955: 103).

3 Fritzílas (2006b) too prefers to see the two objects as representing different substances.

4 I follow Robinson's original designation of the A and B sides, where A is the more completely preserved (on top in Figure 1).

5 Which fact apparently led Eisman and Turnbull to suggest that they were actually working on the handles themselves.

6 The painting is heavily damaged in this area, but it seems possible to me that the side-A figure is kneeling. He is certainly not sitting on the herm's base.

7 Oddly the garlands are not noted by Eisman and Turnbull, nor shown in the drawing by Helen Wilson Kolb that accompanies their article, here used as figure 1.

8 Cf. "Hermes" in LIMC for numerous such examples.
} 
related exceptions do exist: one of a sculptor finishing off a smallish herm in wood, ${ }^{9}$ which is surely not what we have here, and an extremely fragmentary plaque from the workshop of Pheidias at Olympia, which is so exiguous that it can hardly be said to provide a parallel (Burford 1985: 24, fig. 32). In addition to the wreath worn by the side-A herm, both also have wreaths or garlands hanging from the struts they have on their sides in place of arms (Figure 3). ${ }^{10}$

Moving on to the man standing by the herm on each side of the skyphos, we find that he too is similarly portrayed on each side, again with minor variations. On both sides he wears an himation, in contrast to the other figures. On side B, he seems to be motioning to the central figure in the scene, perhaps even helping with the basket that figure carries, and a short portion of a staff is visible in front of him, as it is by the comparable figure on side B of the Thasos fragment. On side A in contrast, he still has his face turned towards the central figure, but his body now addresses the herm which he touches on the face with his right and possibly also his left hand. Eisman and Turnbull put significant emphasis on the approaches to the herms: instead of performing expressions of worship, the figure is, they believe, "a coroplast putting some final touches on the herm." Yet his gesture appears to be one of worship, and similar gestures may be found elsewhere, such as the column krater in Bologna on which both a male and a female worshipper extend their right hands to the faces of two herms (Museo Civico Archeologico, 206 = BACARCH 206078). In fact examples of this kind of gesture are so common that there is a section entitled "Scènes de supplication et d'attouchement d'un hermès" in the LIMC under "Hermes."11

As already mentioned, the two central figures are also differently portrayed on the two sides of the skyphos. The better preserved one from side A seems to be in motion to the left, though his body is presented frontally. His right hand is raised in the direction of his apparent motion, in front of him, and his left fist is on or near his hip, as he looks to the left, back towards the man in front of the herm who is turned towards him. This pose is similar to that of the analogous figure on side B of the Thasos skyphos, whose right hand is at his hip and left arm apparently raised (Maffre 1999). On side $B$, the central figure is holding a basket, perhaps with some help from the figure in front of the herm who is turned towards him away from the herm (in a fragment now lost, but preserved in the original CVA plates). He is facing right, almost surely in motion towards that direction like the corresponding figure on side A. A view of the lower body of each man is blocked by the conical central object, leading to uncertainty about whether they are inside some kind of large open container, or stand behind something which would not necessarily be hollow. It is hard to imagine that the rather animated fragmentary figure on side B is not in motion, and therefore cannot be inside the conical object, but rather must be behind it. The more well preserved figure of side A is covered nearly up to his waist, so that if he is standing inside a container, it must not be very full, leading to the question of why something so empty would need a conical shape. Why not vertical sides or even ones that lean

\footnotetext{
9 Copenhagen, National Museum, 967, 119 = BACARCH 200586.

10 Not noted in the previous literature. Compare the youth seemingly presenting a wreath to a herm on the cup from Capua, now in Copenhagen, BACARCH 204498.

11 LIMC s.v. "Hermes": 113, 130, 143, 144, and esp. in section 14, 153, 154, 155. See also the discussion of herms in De Cesare (1997), and for another example by the Theseus Painter himself, Fritzílas (2006b, inv. 218, pl. 65).
} 
outward to facilitate entry and exit? In keeping with the pottery workshop interpretation, Eisman and Turnbull suggested that on side A the figure was involved in wedging clay, but as the photograph accompanying their article shows, such work areas are usually open, or at least not enclosed with waist-high walls like the ones we have here. Besides if this figure were wedging clay inside a vessel meant to hold it, what would the bent-over figure be doing to the outside of this holding area? They interpret the central figure who holds a basket on side B as carrying clay to or from the area and the central mass as a pile of prepared clay, ready to be carried off. The difference in hatching between the two sides is thus taken to indicate two completely different identities for these two nearly identical structures, and the two central men and the two identical bent-over figures to be engaged in completely different activities. However, whatever they are doing, it is hard to imagine these central figures either inside the objects or working directly on them.

We might usefully add here the evidence of Thasos skyphos. ${ }^{12}$ Unfortunately neither side preserves much of the scene immediately above or at the top of the conical objects. Nevertheless in the short publication of the skyphos, Maffre does not mention evidence of any figures there and enough does remain to suggest that there was none in either depiction; there simply is insufficient space. Instead a man stands facing the central object to its left, behind what is clearly a bent-over figure like the one on the Robinson skyphos. The figures on both sides are described as nude and their genitals are clearly visible, even if the photograph of the figure on side A shows horizontal lines at the waist suggestive of the clothing worn by Robinson's side-A central figure (though they might simply represent stomach fat). If we are to identify these men with our central figures, as seems likely, it becomes clear that ours are not standing inside the central object. Additionally we might imagine that Robinson's men are also either nude or belted like these, and although our side-A figure has been described as wearing a loincloth, the position of his front leg makes it impossible to determine the precise nature of his clothing, and he might have just a belt on.

The final figure to consider is the man who bends over with a large two-handled basket like that once held by the central figure on side B. Here the basket is held sideways, its opening away from the worker, towards the center of the conical object. ${ }^{13}$ The man himself is similarly depicted on both sides, naked to the waist and wearing an animal skin (surely on side B, where the white spots and hooves of the hide are visible, and likely on the other as well). His arms are extended in front of the basket, hands open, palms towards his body. His right hand is clearly visible and the left seems to extend behind the central object. His location next to the central object seems to indicate that his activity involves it. In the context of his identification of the activity as kiln building, it is not surprising that Robinson associated this figure with the application of clay to the outside of an interior made of twigs and osiers, which give the object its hatched appearance. However rather than emptying the basket, the figure appears from the position of his hands to be scooping something into it. Likewise there is no sign of anything spilling from his basket, suggesting it is mostly empty and

\footnotetext{
12 I have not seen these fragments, and am relying on Maffre's description and photograph, reproduced here as Figure 2.

13 The drawing in Eisman and Turnbull mistakenly represents the basket on side B in the upright position.
} 
not being emptied. Although Eisman and Turnbull had a slightly different interpretation from Robinson, they still consider this figure to be carrying clay in his basket. Similar baskets may be seen in numerous outdoor scenes, whether - as most often - in scenes of agricultural or field work, in scenes of sacrifice in which agricultural products appear to make up the contents of the basket, or, in at least one case, in a depiction of an athlete who fills a basket with the dirt he is picking on the field. ${ }^{14}$

We are left then with a cast of characters who seem to be involved with some activity dealing with the large object at the center of each side, to which we must now turn. As noted by all commentators, these conical objects are unusual in Greek vase painting, and this, coupled with the rest of the scene which clearly pointed to a context of manual labor, led to their interpretation by Robinson as "more than likely a kiln."

Although Robinson cited a few pottery kilns that had been excavated or portrayed in Greek painting, the iconography of pottery kilns in Greek art has now been well established and certainly does not match the central object at all, as Eisman and Turnbull correctly noted. As depicted on numerous of the Corinthian dedicatory plaques from Penteskouphia, and discovered in several excavations, the ancient pottery kiln was approximately the height of a man or even taller, and dome-shaped with a low stoking tunnel leading into it. On the plaques, its surface is shown as smooth, never with hatching of any kind (cf. the reconstructions in Cook 1959; Scheibler 1995). It is therefore little like the clearly smaller object on this skyphos, even if we might consider ours still under construction. Beazley's suggestion and that of Eisman and Turnbull that some of the workmen are gathering or working with clay also neglects what we know of how clay is depicted: as a lumpy, smooth mass. ${ }^{15}$

As already mentioned, it was Ingeborg Scheibler who first suggested that the scene here was actually agricultural in nature, and had nothing to do with pottery production. She relied on her observation of the garlands on the large vessels under the handles, as well as a single parallel for the central object. She is certainly correct, but the comparandum she cites, a red-figure belly amphora from the Kerameikos, does not provide an unambiguous parallel (Knigge and Tancke 2005, inv. 203, pl. 70-71). It depicts a man at right, standing with an oar-like threshing shovel in his right hand and a basket in his left. ${ }^{16} \mathrm{He}$ faces a female figure at left, who holds a staff or scepter, perhaps marking her as Demeter. Between them is what looks like a smaller version of the object found on the Robinson skyphos. While this central object barely comes to the man's knees, it has the same simple hatching and the truncated-conical shape as the one on the Robinson skyphos. Given the context, it seems reasonable to assume it too is agricultural in nature, but Knigge, who published the image, had expressed doubt: "pile of grain?," perhaps due to the rarity of this kind of depiction. With the exception of Fritzílas, who has expanded on Scheibler's explanation (2006a, b), subsequent discussions of this scene have expressed that same doubt, even as they leaned towards Scheibler's interpretation (Borgers 2003: 120-121; Stissi 2002: 80-81; Williams 2009: 306).

14 For agricultural work BACARCH 302815, 205648, 301819; sacrifice BACARCH 14663; the athlete BACARCH 203435. We will return to two other examples of the basket in a similar context below.

15 Cf. the Athena with horse, Berlin, Antikensammlung, F2415 = BACARCH 209569, and clay miners of the Penteskouphia plaque = BACARCH 209569. Pace Eisman and Turnbull (1978: 397), the central object cannot therefore "reasonably be interpreted as clay."

16 On winnowing in general, Harrison 1903. 
Any doubts about the correctness of Scheibler's interpretation may be removed by adducing other, closer parallels to the central object. In fact the best comparanda for the scene are not to be found in Greece, but in Egypt, ${ }^{17}$ a location renowned in antiquity for its great agricultural wealth, especially in grain production. ${ }^{18}$ It is therefore perhaps not surprising to find in extant wall paintings many scenes of agricultural work which depict all phases of the process, from sowing through granary storage (exx. Fritzílas 2006b, pl. 108). ${ }^{19}$ Although most of the examples are from the Old Kingdom, and therefore significantly earlier than the one on our skyphos, the similarity of nearly all relevant details leaves no doubt that the same objects are being portrayed. As Scheibler realized, the object is in fact a pile of grain, threshed, winnowed and being measured and carried away in baskets. In the Egyptian examples, the grain is typically portrayed with stippling or the same hatching as on our skyphos.

Although not all tombs show the full sequence, it is evident from the many examples that piles like ours are depicted at several points after the harvest is completed. The first pile is created by men throwing together bundles of cut grain, which are usually transported by donkeys. These piles resemble ours in outline, having a flat top and the overall truncated-conical appearance. They are however much taller, typically at least as tall as the workmen, and are never attended by men with baskets (e.g., Robins 1997: 23, fig. 13, scene at bottom right). The second pile appears as the grain is threshed by being trampled by animals. These piles are more similar in size to ours, but with rounded tops, and are also never attended by men with baskets. In addition the presence of animals clearly identifies them. This threshed grain is then gathered by men with pitchforks who create another tall, flat-topped pile, which is often decorated with triangular objects, which appear to be on the top edges of the pile. These piles are in turn supplied to the winnowers by men with pitchforks. After winnowing a final pile is created, which is shorter than the workmen, and is removed by men with baskets. It is this last pile that appears to be most analogous to the one on the Robinson skyphos.

Two examples of this pile may be seen in Figures 4 and 5. The first shows a drawing of an agricultural scene from Thebes in the great 19th-century compendium of Wilkinson (1847: 86, in vol. 4 of the 3rd ed.), while in Figure 5 there is a pottery model of a granary in Norwich with the scene painted on its side (Blackman 1920: 208). As on the Robinson vase, unshirted workmen bend over at the foot of the hatched pile of grain, with baskets or barrels tipped over in front of them to be filled using their hands, with arms sometimes outstretched as those on the skyphos. The Egyptians fill baskets as a mechanism for measuring the grain, which is then placed in sacks and brought to a granary. (These last two stages frequently do not appear in the preserved scenes.) Egyptian depictions of the removal of grain also typically include one or more

\footnotetext{
17 See Morris \& Papadopoulos (2004) for an appeal to Egyptian parallels in for the "rich Athenian lady" of the Athenian agora, esp. 223 on the distance, both physical and temporal between Greece and Egypt. Also Harrison (1904) for parallels between Egyptian and Greek agricultural practice, and the use of ethnographic parallels.

18 Diodorus Siculus describes the ease with which large harvests were made in Egypt; cf. esp. the mention

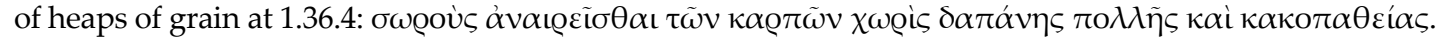
19 The Oxford Egypt Expedition (http://ads.ahds.ac.uk/catalogue/archive/oee_ahrc_2006/index.cfm) has a more complete inventory, though few images, and a somewhat different typology of the individual agricultural activities.
} 
scribes who record the amount of grain present, sometimes in the presence of an overseer. These scribes are often seated on top of the grain piles, a position which recalls our central male figure, though he very clearly stands behind the pile and does not sit on it. Similarly just as there is often an overseer of some kind in the Egyptian example, our right-most man seems to have some kind of supervisory role, dressed as he is in the himation with a staff and some detachment from the physical labor of the central scene.

Reference to these various Egyptian examples is not meant to suggest that Greek painters of the Archaic period relied on centuries-old foreign models for their designs. Instead these common shared features of Mediterranean agricultural practice are mainly responsible for these similarities.

As already noted, there are indeed very few other examples of grain so portrayed in Greek vase painting. Closest is the Kerameikos example discussed above. The fourth example I am aware of is found on a pyxis lid which depicts an odd youth, with small horns on his head, sitting on what appears to be a pile like ours, though decorated with dots instead of hatching (Ure 1949: 19-20). ${ }^{20}$ He is accompanied by a series of objects which recall both our scene and that from the Kerameikos: a basket to his right filled with agricultural objects, including an ear of wheat, and to his left a large fork and something like an oar, which Ure suggests may be a winnowing fan. From the context of the scene, both Ure and Rose leaned towards the possibility that he sits on a pile of grain. ${ }^{21}$

The presence of the winnowing shovel, $\pi \tau v$ ov, in the Kerameikos and Boeotian scenes leads to a possible interpretation of another feature of the Thasos depiction: Fritzílas suggests that a short fragment of a straight white object seen in the hands of the upright worker on side B of the Thasos skyphos is also a winnowing shovel. This is entirely possible, especially since the Theseus Painter often paints white staffs in the hands of black-figure men on his pots (exx. Fritzílas 2006b, pl. 108). We might wonder then whether the worker is decorating the top of the pile with his ptuon as described in Theocritus Id. 7.155, ${ }^{22}$ in which case it is worth noting other possible decorations in the red line seen at the top of the Thasos skyphos, Maffre's "filet coloré," (1999: 270) and the garlands on the amphoras under the handles of the Robinson skyphos.

\section{Ritual connections?}

What are we to make of this scene then? Harvest scenes were surely common enough in the ancient Greek countryside that this could be simply a generic depiction of such work, yet the very difficulty with which this scene has been identified attests to its unusual nature. On the other hand, the presence of the garlands on the amphoras, the herm which is typically present in scenes of sacrifice, and even the shape of the vessel

\footnotetext{
20 See also Rose 1952 and, in response, Ure 1952; further comments in Ure 1969. Boardman (1970: 195) interprets the figure as Pan, though this does not affect my consideration of the pile on which he sits.

21 Ure: "it is a question whether the deity who holds it is not himself perched upon the corn heap," and Rose: "a small elevation which the artist has covered with round spots, quite possibly intending it for a heap of threshed corn." Ure (1954 CVA edition that contains the pyxis) describes the figure as sitting "on...possibly a heap of corn."

22 For an Egyptian example of this practice, see Harrison (1904: fig. 1).
} 
itself, ${ }^{23}$ all hint at a possible connection with some festival: Scheibler herself discussed the scene in the context of other skyphoi depicting ritual scenes (Scheibler 2000). ${ }^{24}$ Not to be forgotten here too is Robinson's observation that fillets are "worn by all the men," hardly everyday field attire (1938: 11). ${ }^{25}$ The basket-wielder on side B wears the skin of a fawn, to judge by the hooves that dangle from his waist and the white spots that decorate it. This is normally the attire of the worshippers of Dionysos, the maenads and satyrs. ${ }^{26}$ Robinson also says that "[t]here are a few scattered white spots on the drapery." This is an understatement. Although they now have no color, circular spots are to be found on the clothing of every figure as well as on the vertical support of the herm on side A (Figure 6); they are nowhere else on the surface. ${ }^{27}$ If we correctly identify these as Robinson's white spots - and the similarly faded wreath on the head of the bent-over figure on side B strongly suggests that we should-then it seems that everyone in the image wears spotted clothing, hardly an every-day occurrence. We should also not forget the already mentioned garlands hanging from the herms' struts.

The horned youth sitting on the grain heap on the pyxis from Reading whom Ure identified as Dionysos also wears a fawn skin, and the associations of the skyphos itself with Dionysos only add to the possible connection with the god. It is of course hard not to think also of Demeter owoĩ ı५, "Giver of heaps of corn," as she is called in the Orphic hymn dedicated to her (40.5), especially in light of her likely appearance on the Kerameikos amphora. Although there is not a specific cultic connection, the two gods are also joined by Euripides in the Bacchae (274-285): Demeter who brings food, and Dionysos wine. Just as the skin recalls ritual dance, so does the unusual pose of the central figure, found also on the Thasos skyphos. With the herm and Dionysos, we are perhaps in the context of the Choes festival (Malagardis 1985), ${ }^{28}$ but this all requires broader consideration, including the context of the rest of the Theseus Painter's output.

\section{Confusion about kilns (and forges)}

Finally it is worth considering the nature of the errors that led to the mis-identification of the scene as one of a pottery workshop. As discussed above, the artistic convention of the cross-hatched pile of grain is hardly common in extant Greek vase painting. Nevertheless several other factors militated against identification of the scene with a workshop. Robinson began this with his interpretation of the youths under the handles as potters, despite the presence of the garlands. Indeed he interpreted one figure

\footnotetext{
23 Borgers (2003: 136) on the skyphos in ritual.

24 I am also partial to the notion that many apparently generic scenes should be reconsidered. See Ferrari (2003) for a theoretical treatment and Neils (2004) for a concrete application, as it turns out in another kind of "workshop" scene. Cf. also the remarks of Scheffer (1992: 136-137) on the likely ritual meaning of grinding scenes like those examined by Neils.

25 Contra Fritzílas (2006a: 399), who considers the fillets and amphora garlands part of the festive atmosphere of the harvest.

26 Lawler (1952: 323): “It is quite clear that a fawn skin, nebris, or a conventionalized representation of one, was frequently worn by dancers, both men and women, in rituals of Dionysus. Dionysiac dancers are sometimes called 'fawns;' and the verb nebrizein, 'to play the fawn,' becomes a technical term for participation in the mysteries of Dionysus."

27 From personal examination of the skyphos.

28 More broadly on the festival of the Anthesterion, Parke (1977: 108 f.).
} 
as "impressing the design on the shoulder." Yet if the shoulder were so soft that a firm thumb could make an impression upon it, how could the entire amphora be standing upright? Perhaps Eisman and Turnbull were cognizant of this when they suggested that the figures under the handles were attaching handles to their amphoras.

Next was the shape of the conical object. If the depiction of grain was rare, so would have been such a kiln; there was no parallel for it. An interpretation that might have been a stretch for Robinson in the 1930s was no longer tenable 40 years later, when there had been numerous publications of Greek pottery kilns, most famously perhaps Noble's (1965) on the production of Greek pottery. Shortly thereafter followed Zimmer's work (1982) on workshop depictions in Greek art. Such confusion about kilns may be found elsewhere as well: Eisman and Turnbull-among othersalso mis-identified the tall, decidedly un-domed structure on a lekythos in Providence as a kiln, even as they saw that the Robinson structure was not. ${ }^{29} \mathrm{~A}$ third misidentification also helped to support their argument for the role of the herm in workshops described above: the fairly common scene painted on a column krater in the British Museum of a sacrifice in front of a herm, but interpreted by them as a blacksmith's shop. ${ }^{30}$

In short there was almost a willful effort to see this as a pottery workshop, instead of some other kind of scene. What the entire approach to the uncertainties of the scene reveals is a scholarly tendency to relate ambiguous or uncertain activities to the world of the potter. Gill and Vickers (1990) have explored the desire to elevate the work of ancient ceramicists to a high art, and I suggest that these previous efforts at explaining the Robinson skyphos spring from a similar desire to imagine the painter portraying his own daily life in his art. ${ }^{31}$ Instead, as Scheibler and others have argued, we have on the Robinson skyphos and on the nearly identical Thasos pot a scene of grain collection after threshing and winnowing is complete, likely in the context of a Greek festival.

Professor John D. Muccigrosso

Department of Classics, Drew University

E-mail: jmuccigr@drew.edu

\section{BIBLIOGRAPHY}

Beazley, John D. (1956) Attic Black-figure Vase-painters. Oxford: Clarendon Press.

Blackman, Aylward M. (1920) 'A Painted Pottery Model of a Granary: In the Collection of the Late Jeremiah James Colman, Esq., of Carrow House, Norwich.' - Journal of Egyptian Archaeology 6.3, 206-208.

Boardman, John (1970) 'A Sam Wide Group Cup in Oxford.' - JHS 90, 194-195.

Borgers, Olaf E. (2003) The Theseus Painter: Style, Shapes and Iconography. University of Amsterdam.

29 BACARCH 207933 = Providence 25109. Cf. the bibliography in BACARCH for other similar identifications. See Trümper (2003: 52, fig. 7-9) for a more satisfactory discussion.

30 BACARCH 30320 = BM 362. They were followed in this by A. J. Paul (Russell \& Luckner 1994).

31 Such often mistaken efforts to see pottery manufacture when it is not in fact present was the topic of my 2006 AIA poster, and one which I intend to continue to expand upon in an upcoming publication. 
Burford, Alison (1985) Künstler und Handwerker in Griechenland und Rom. Mainz am Rhein: P. von Zabern.

Cook, Robert M. (1959) 'Die Bedeutung der bemalten Keramik für den griechischen Handel.' - Jahrbuch des Deutschen Archäologischen Instituts 74, 114-123.

De Cesare, Monica (1997) Le statue in immagine: studi sulle raffigurazioni di statue nella pittura vascolare greca. Rome: L'Erma di Bretschneider.

Eisman, Michael M.; Turnbull, Lucy (1978) 'Robinson's Kiln Skyphos.' - AJA 82.3, 394-399.

Ferrari, Gloria (2003) 'Myth and Genre on Athenian Vases.' - CA 22.1, 37-54.

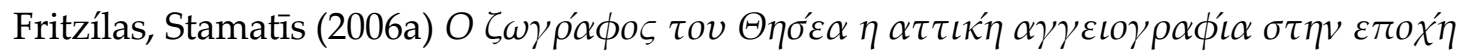

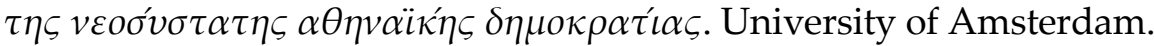

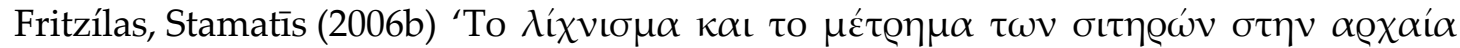

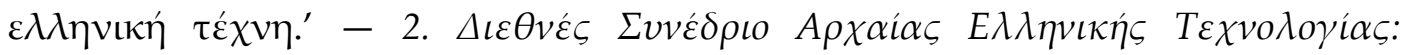

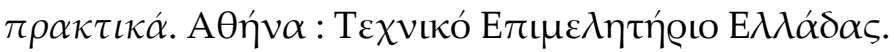

Gill, David W. J.; Vickers, Michael (1990) ‘Reflected Glory: Pottery and Precious Metal in Classical Greece.' - DAIR 105, 1-30.

Harrison, Jane E. (1903) 'Mystica Vannus Iacchi.' - JHS 23, 292-324.

Harrison,Jane E. (1904) 'Mystica Vannus Iacchi (Continued).' - JHS 24, 241-254.

Knigge, Ursula; Tancke, Karin (2005) Der Bau Z. München: Hirmer.

Lawler, Lillian B. (1952) '"Dancing Herds of Animals."' - CJ 47.8, 317-324.

Maffre, Jean-Jacques (1999) 'Une Nouvelle représentation de potiers au travail: un skyphos attique à figures noires de l'Artémision de Thasos.' - Kovкoú $\lambda \eta$ -

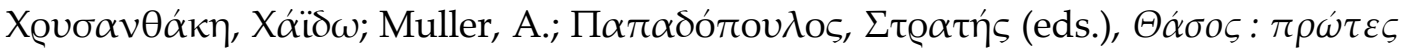

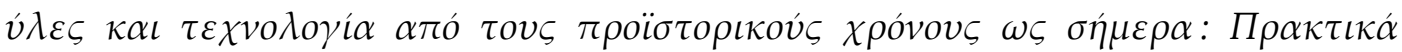

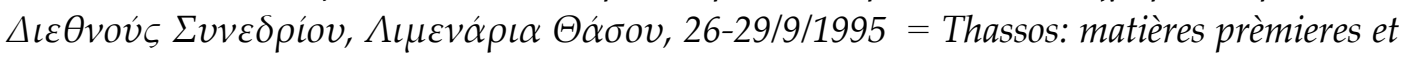
technologie de la préhistoire à nos jours. Athens: École française d'Athènes, 269-278.

Malagardis, Athanasia (1985) 'Deux temps d'une fête athénienne sur un skyphos attique.' - AntKunst 28.2, 71-92.

Morris, Sarah P.; Papadopoulos, John K. (2004) 'Of Granaries and Games: Egyptian Stowaways in an Athenian Chest.' - Hesperia Supplements 33, 225-242.

Neils, Jenifer (2004) 'Kitchen or Cult? Women with Mortars and Pestles.' - Keay, S.; Moser, S.; Sparkes, B. A. (eds.), Greek Art in View: Essays in Honour of Brian Sparkes. Oxford: Oxbow, 54-62.

Noble, Joseph V. (1965) The Techniques of Painted Attic Pottery. New York: WatsonGuptill Publications.

Parke, Herbert William (1977) Festivals of the Athenians. Ithaca, N.Y.: Cornell University Press.

Robins, Gay (1997) The Art of Ancient Egypt. Cambridge, MA: Harvard University Press.

Robinson, David M.; Freeman, Sarah E. (1938) Corpus Vasorum Antiquorum 7, United States of America. The Robinson Collection, Baltimore, MD, Fasc. 3. Cambridge, MA: Harvard University Press.

Robinson, David M.; Hanfmann, George M. A. (1961) The David Moore Robinson Bequest of Classical Art and Antiquities: a Special Exhibition May 1 to Sept. 20. Cambridge, MA: President and Fellows of Harvard College.

Rose, H. J. (1952) ‘Demeter and Dionysos.' - JHS 72, 121. 
Russell, Pamela J.; Luckner, Kurt T. (1994) Ceramics and Society: Making and Marketing Ancient Greek Pottery: The Tampa Museum of Art, February 20 to May 15, 1994. Tampa, FL: The Tampa Museum of Art.

Scheffer, Charlotte (1992) 'Boeotian Festival Scenes: Competition, Consumption, and Cult in Archaic Black Figure.' - Hägg, Robin (ed.), The Iconography of Greek Cult in the Archaic and Classical Periods. (Kernos; suppl. 1.) Liège; Athens: Centre d'étude de la religion grecque antique, 117-141.

Scheibler, Ingeborg (1987) 'Bild und Gefäss: Zur ikonographischen und funktionalen Bedeutung der attischen Bildfeldamphoren.' - JdI 102.1, 57-118.

Scheibler, Ingeborg (1995) Griechische Töpferkunst: Herstellung, Handel und Gebrauch der antiken Tongefässe. München: Beck.

Scheibler, Ingeborg (2000) 'Attische Skyphoi für attische Feste.' - AntKunst 43.1, 17-43.

Stissi, Vincenzo Vladimir (2002) Pottery to the People. The Production, Distribution and Consumption of Decorated Pottery in the Greek World in the Archaic Period (650-480 BC). University of Amsterdam.

Trümper, Monika (2003) 'Grobschlächtige Arbeiter oder durchtrainierte Athleten? Zur singulären Darstellung einer Badeszene auf eine spätarchaischen schwarzfigurigen Lekythos.' - AA 8.2, 45-64.

Ure, Annie D. (1949) 'Boeotian Haloa.' - JHS 69, 18-24.

Ure, Annie D. (1952) 'The God with the Winnowing-fan.' - JHS 72, 121.

Ure, Annie D. (1955) 'Krokotos and White Heron.' - JHS 75, 90-103.

Ure, Annie D. (1969) ‘Demeter and Dionysos on Acrocorinth.' - JHS 89, 120-121.

Ure, Percy N.; Ure, Annie D. (1954) Corpus Vasorum Antiquorum. Great Britain, Fasc. 12. University of Reading, Fasc. 1. London: Oxford University Press.

Wilkinson, John Gardner (1847) The Manners and Customs of the Ancient Egyptians: Including Their Private Life, Government, Laws, Arts, Manufactures, Religion, and Early History: Derived from a Comparison of the Paintings, Sculptures, and Monuments Still Existing, with the Accounts of Ancient Authors. London: J. Murray.

Williams, Dyfri (2009) 'Picturing Potters and Painters.' - Oakley, John H.; Palagia, Olga (eds.), Athenian Potters and Painters II. Oxford: Oxbow, 306-317.

Zimmer, Gerhard (1982) Antike Werkstattbilder. Berlin: Mann. 

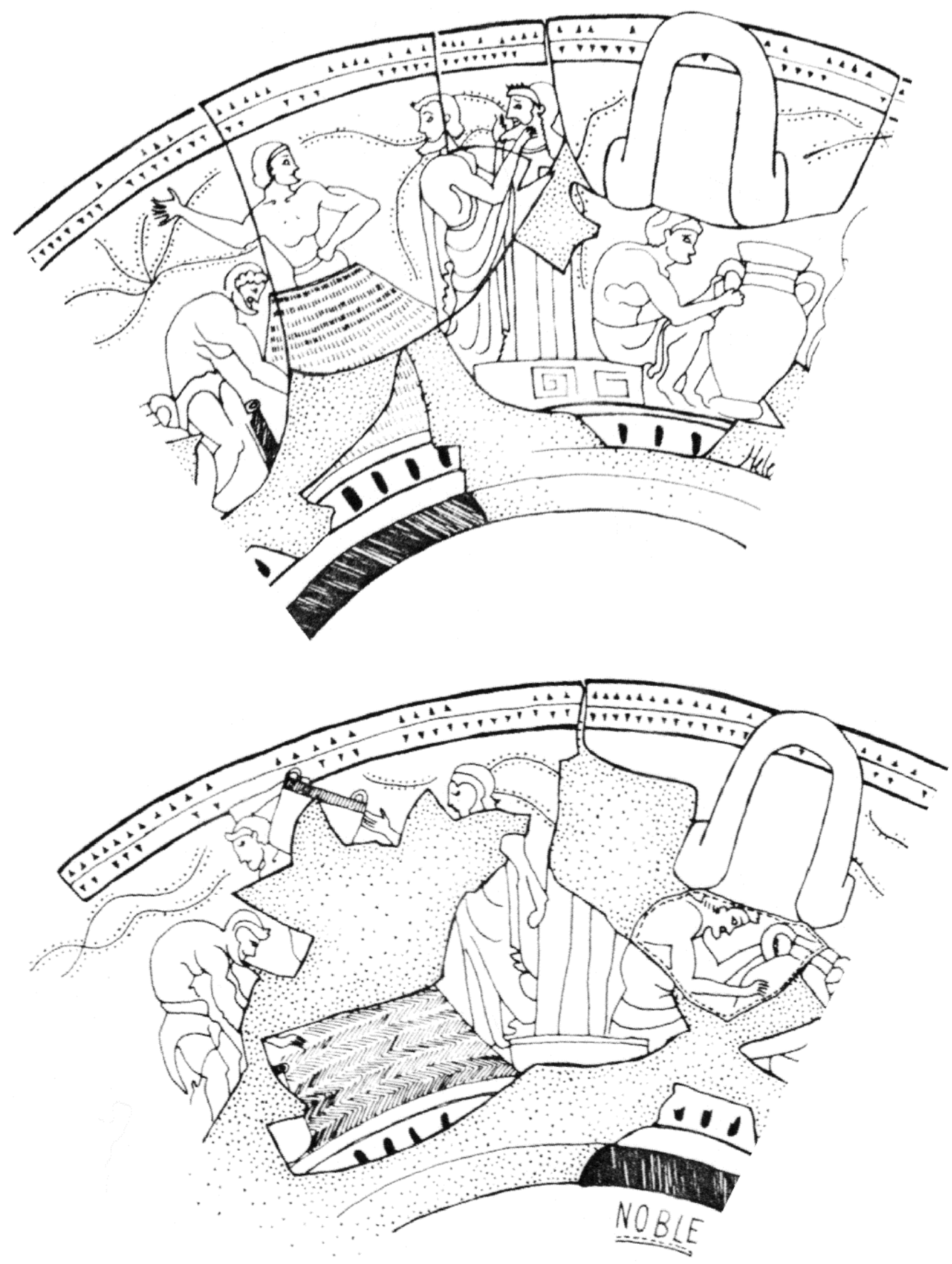

Fig. 1. Modified version of drawing from Eisman and Turnbull (1978), divided to align similar figures on both sides. 

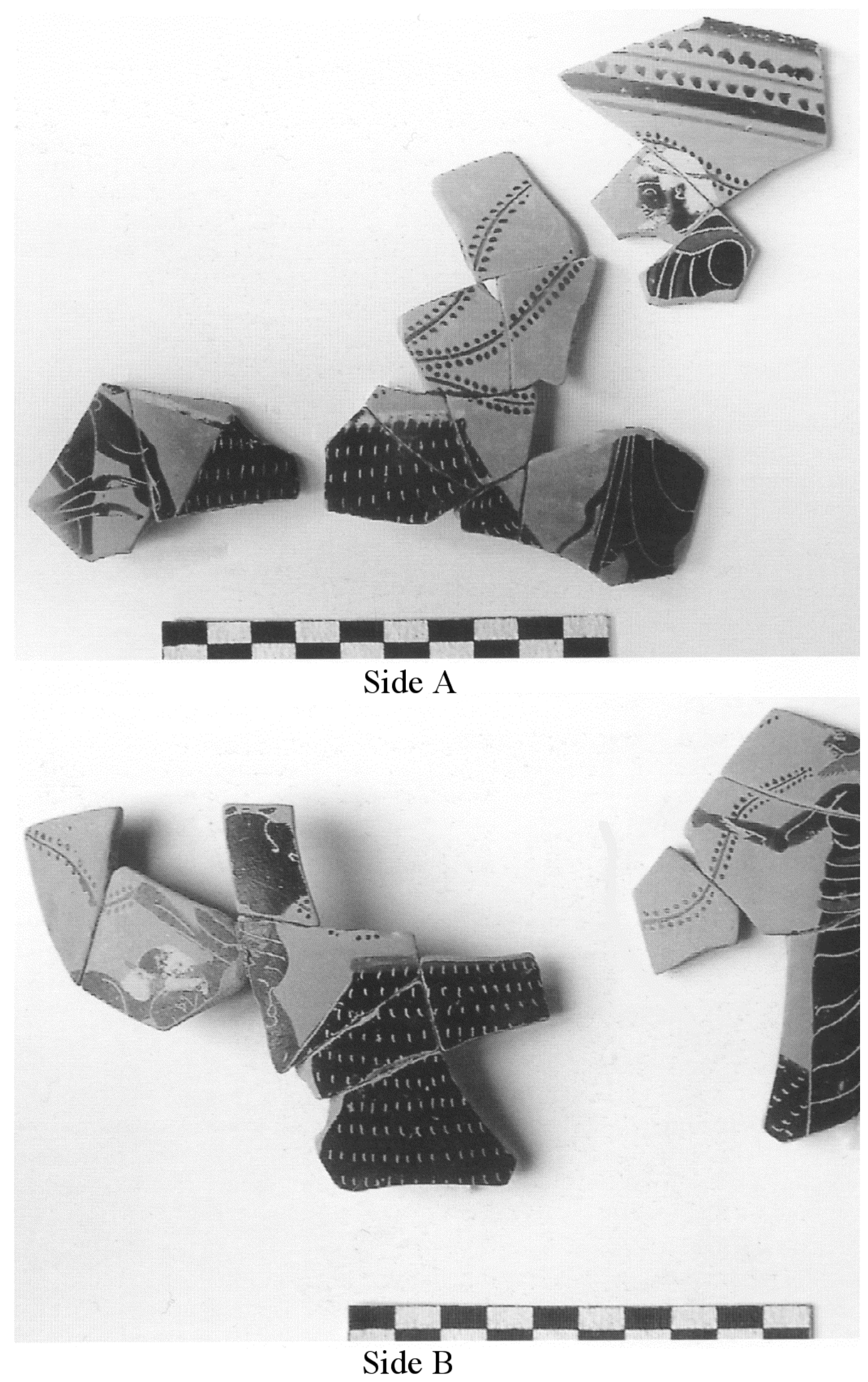

Fig. 2. Thasos skyphos (Maffre 1999). 


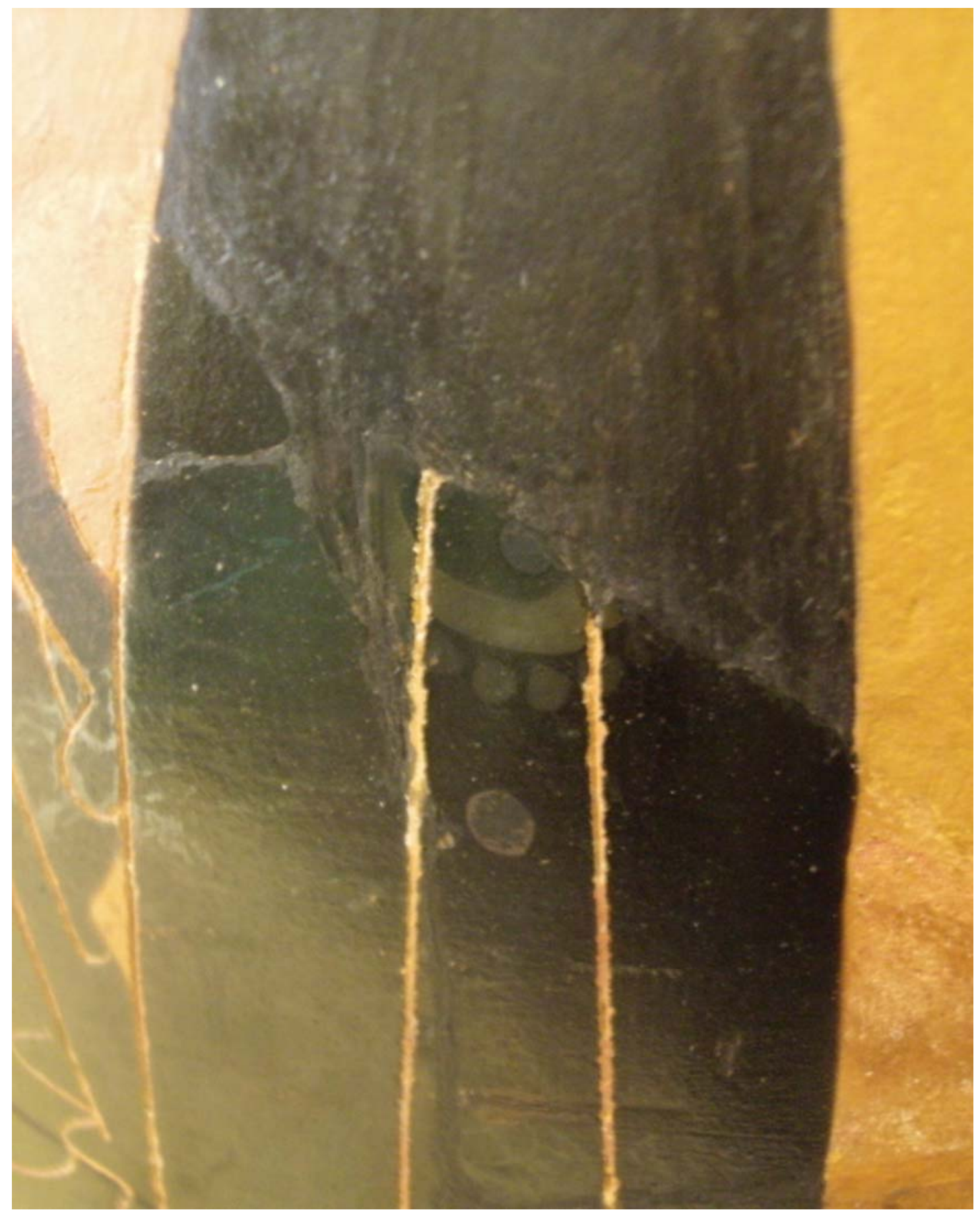

Fig. 3. Now much faded wreath hanging from strut of side-B herm (at Harvard University, Sackler Museum; by author).

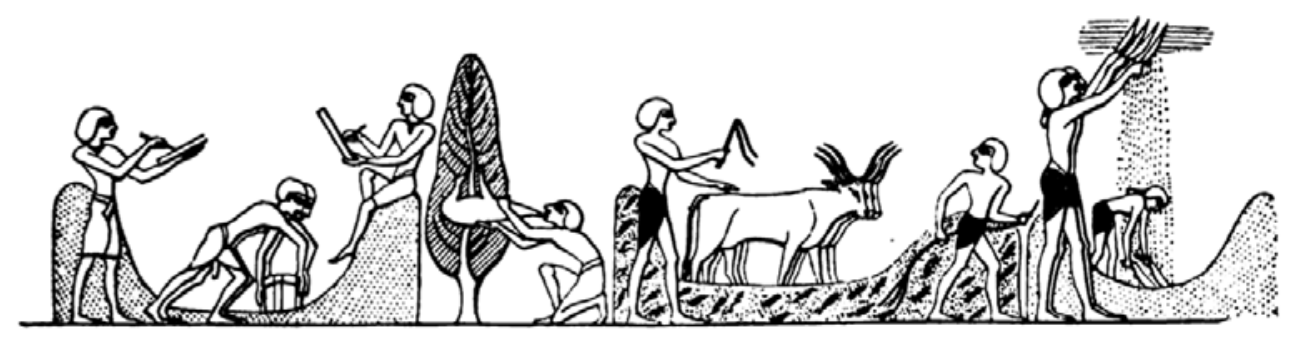

Fig. 4. Agricultural scene showing, from right to left: winnowing, threshing, measuring. 


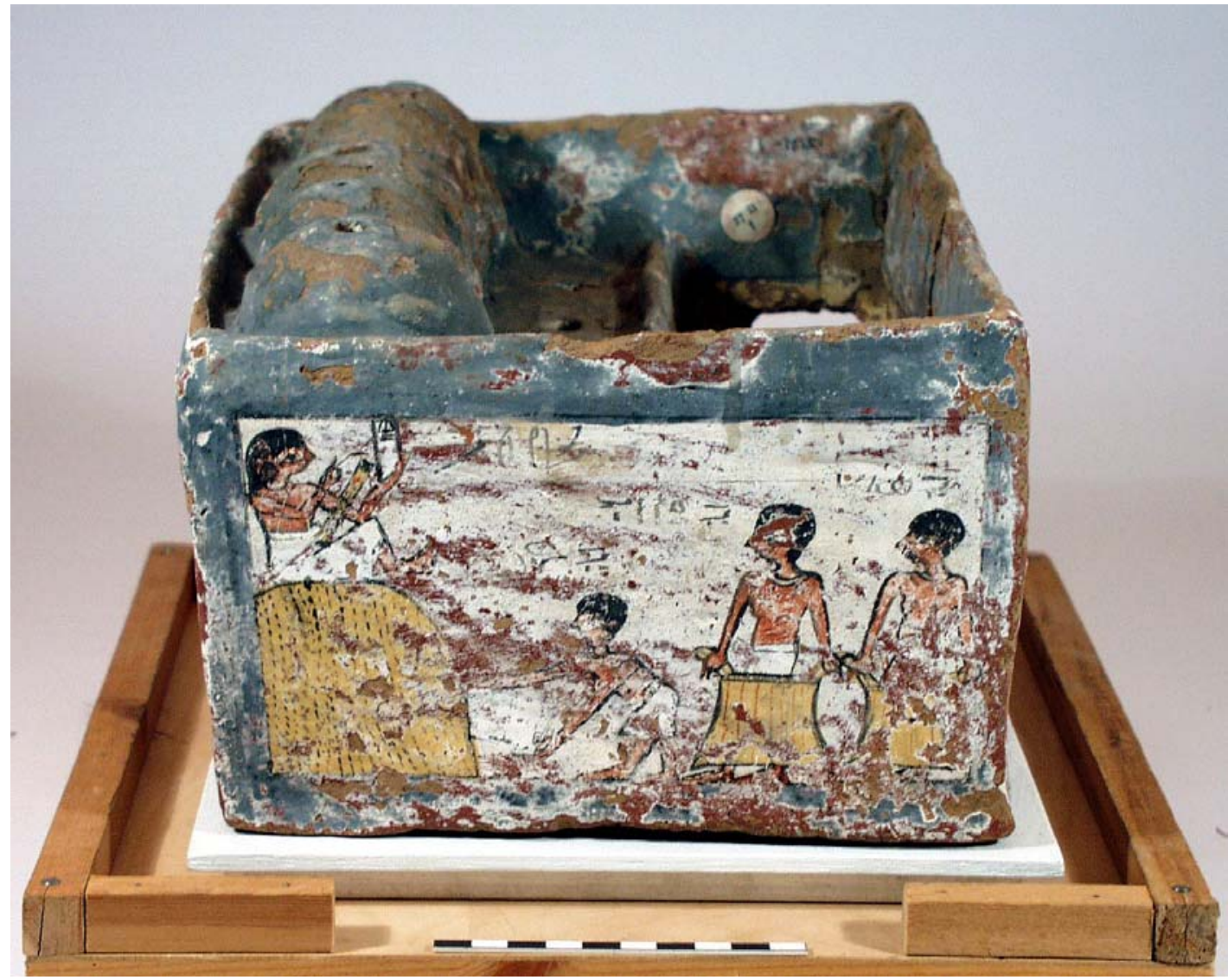

Fig. 5. Grain inventory from Norwich ( Norwich Castle Museum and Art Gallery).

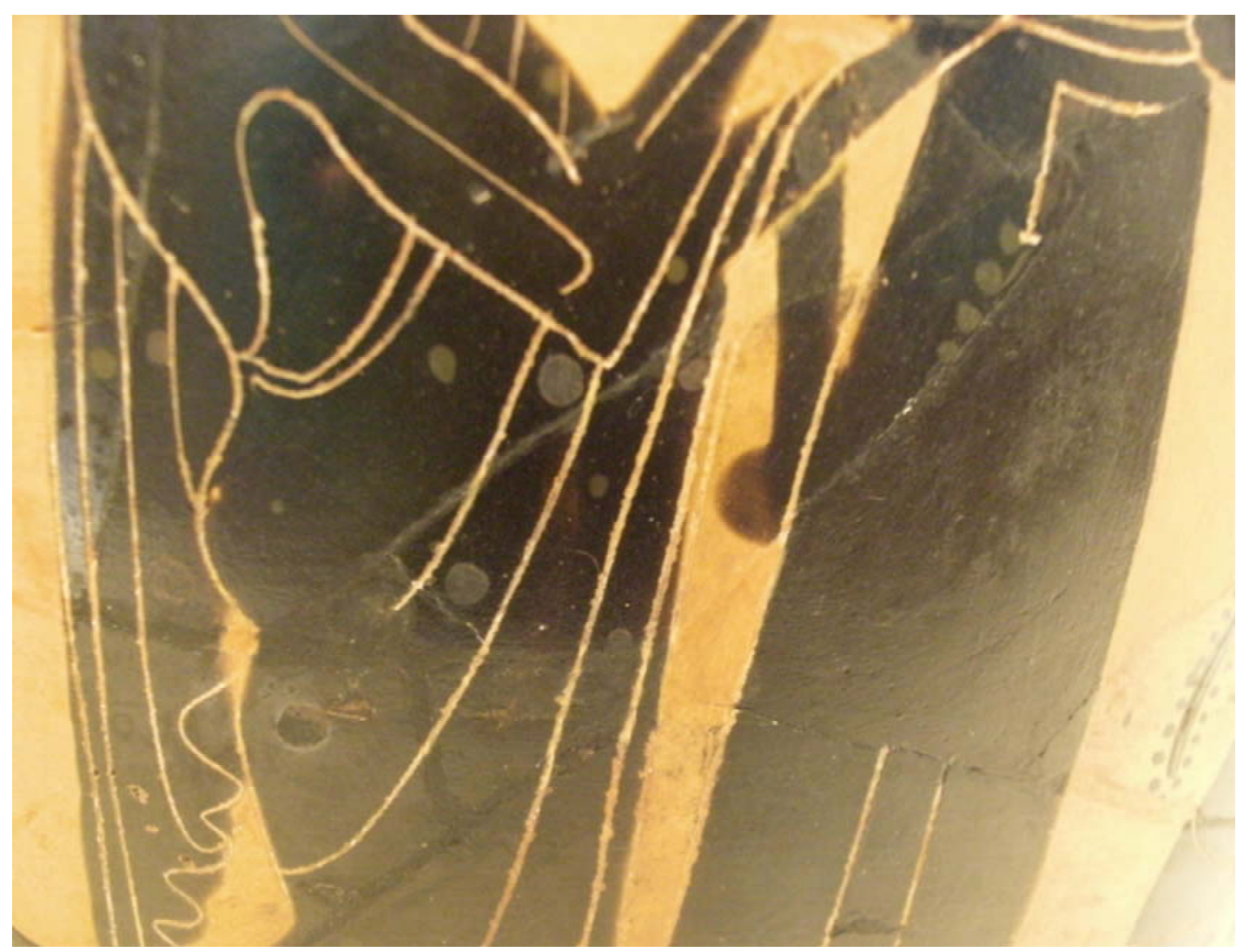

Fig. 6. Close-up of Side B showing faded circular spots on clothing (by author). 